\title{
Vaccination with live attenuated simian immunodeficiency virus causes dynamic changes in intestinal CD4+CCR5+ T cells
}

\author{
Bo Li ${ }^{1}$, Neil Berry², Claire Ham², Deborah Ferguson², Deborah Smith², Joanna Hall², Mark Page², \\ Ruby Quartey-Papafio ${ }^{2}$, William Elsley², Mark Robinson ${ }^{2}$, Neil Almond ${ }^{2}$, Richard Stebbings ${ }^{{ }^{*}}$
}

\begin{abstract}
Background: Vaccination with live attenuated SIV can protect against detectable infection with wild-type virus. We have investigated whether target cell depletion contributes to the protection observed. Following vaccination with live attenuated SIV the frequency of intestinal CD4+CCR5+ T cells, an early target of wild-type SIV infection and destruction, was determined at days 3, 7, 10, 21 and 125 post inoculation.

Results: In naive controls, modest frequencies of intestinal CD4+CCR5+ T cells were predominantly found within the LPL $T_{T r M-1}$ and IEL $T_{T r M-2}$ subsets. At day 3, LPL and IEL CD4+CCR5+ $T_{E M}$ cells were dramatically increased whilst less differentiated subsets were greatly reduced, consistent with activation-induced maturation. CCR5 expression remained high at day 7, although there was a shift in subset balance from CD4+CCR5 $+T_{E M}$ to less differentiated $T_{\text {TrM-2 }}$ cells. This increase in intestinal CD4+CCR5 + T cells preceded the peak of SIV RNA plasma loads measured at day 10. Greater than $65.9 \%$ depletion of intestinal CD4+CCR5 $+T$ cells followed at day 10, but overall CD4+ T cell homeostasis was maintained by increased CD4+CCR5- T cells. At days 21 and 125, high numbers of intestinal CD4+ CCR5- naive $T_{N}$ cells were detected concurrent with greatly increased CD4+CCR5+ LPL $T_{T r M-2}$ and IEL $T_{E M}$ cells at day 125, yet SIV RNA plasma loads remained low.
\end{abstract}

Conclusions: This increase in intestinal CD4+CCR5 + T cells, following vaccination with live attenuated SIV, does not correlate with target cell depletion as a mechanism of protection. Instead, increased intestinal CD4+CCR5+ T cells may correlate with or contribute to the protection conferred by vaccination with live attenuated SIV.

\section{Background}

Non-human primates (NHP) challenged with simian immunodeficiency virus (SIV) or engineered SIV/HIV-1 chimeras (SHIV) have been used as models to evaluate the efficacy of a wide variety of candidate AIDS vaccine approaches for more than two decades [1-6]. Amongst the vaccine strategies evaluated in NHP models, vaccination with live attenuated SIV/SHIV has proven to be the most effective at providing broad protective immunity against a wide range of SIV and SHIV challenges [7-15]. However, concerns regarding the safety of a live attenuated SIV or HIV vaccine have to date limited further pursuit of this approach as an AIDS vaccine strategy in

\footnotetext{
* Correspondence: richard.stebbings@nibsc.hpa.org.uk

'Biotherapeutics Group, National Institute of Biological Standards and

Control/Health Protection Agency, Potters Bar, Hertfordshire, UK

Full list of author information is available at the end of the article
}

the clinic [16-20]. Nevertheless, the potency of this vaccine protection has led to further studies in NHP models to provide information on the mechanisms of protective immunity that a safe and effective human vaccine may have to reproduce to be of equal efficacy [21].

Many groups have attempted to identify robust correlates of protection amongst the adaptive immune responses elicited by live attenuated SIV vaccines. Unfortunately a confusing picture has developed, with different groups reporting either partial, full or no correlation with various measures of adaptive immunity [22-39]. This confusion may have resulted from the range of different NHP models used for these studies: using different vaccines, different challenge viruses and different species of macaque. However, since the efficacy of live attenuated vaccines appears to correlate inversely

\section{C) Biomed Central}


with the level of attenuation $[40,41]$ and the most effective vaccines persist and replicate in the host [42], then it is possible that innate responses may also contribute to the vaccine effect $[36,37]$. This would appear to be the case with live attenuated vaccines that have been reported to protect within as little as 3 weeks vaccination when adaptive antiviral immune responses are low or absent [43].

The gut-associated lymphoid tissue (GALT) constitutes a large immune compartment within the body [44-47] which, compared to other lymphoid compartments, is rich in CD4+ T cells expressing CCR5 [48-50], a preferential co-receptor for HIV and SIV infection [51-53]. Early depletion of intestinal CD4+CCR5+ $\mathrm{T}$ cells is now a recognised hallmark of wild-type SIV/ HIV infection resulting from the destruction of virus infected target cells $[46,48,54-57]$. It could be hypothesised that if live attenuated SIV vaccines caused a similar loss of CD4+CCR5 + T cells in this compartment, then this depletion of target cells could contribute to the vaccine effect. However, it has been reported that vaccination of rhesus macaques with live attenuated SIV does not cause significant loss of intestinal CD4+ T cells $[48,58]$. Moreover, it has recently been reported that vaccination with attenuated SIV causes a transient increase in activated CD4+ memory T cells [58]. Nonetheless, dynamic changes in CCR 5 expression within intestinal $C D 4+T$ cell memory subsets were not assessed in detail, nor have these types of studies been performed in models involving cynomolgus macaques.

In the present study, we have characterised the impact on CD4+CCR5+ intestinal T cell memory subsets following inoculation with a potent live nef-attenuated SIV vaccine in the cynomolgus macaque model. These data have revealed that vaccination results in dramatic dynamic changes in key lymphocyte subsets in the intestinal tract that appear to be more consistent with immune activation, likely to induce innate and adaptive responses, than target cell depletion. These changes may contribute not only to the kinetics of vaccine protection, but also to the kinetics of virus replication.

\section{Results}

Attenuated SIV virus loads in blood and lymphoid tissues peak at day 10

Following inoculation with live attenuated SIV, plasma SIV RNA loads (copies/ml) increased significantly at days 3 and $7\left(\log _{10} 2.90 \pm 0.08, \mathrm{p}<0.001\right.$ and $\log _{10}$ $4.85 \pm 0.14, \mathrm{p}<0.001$ respectively) compared to naive controls, peaking at day $10\left(\log _{10} 5.54 \pm 0.15, \mathrm{p}<0.001\right.$; Figure 1). Compared with day 10, SIV RNA loads declined significantly by days 14 and $21\left(\log _{10} 4.57 \pm\right.$ $0.28, \mathrm{p}<0.001$ and $\log _{10} 3.75 \pm 0.25, \mathrm{p}<0.001$, respectively) onwards to nadir between days 84 and $125\left(\log _{10}\right.$

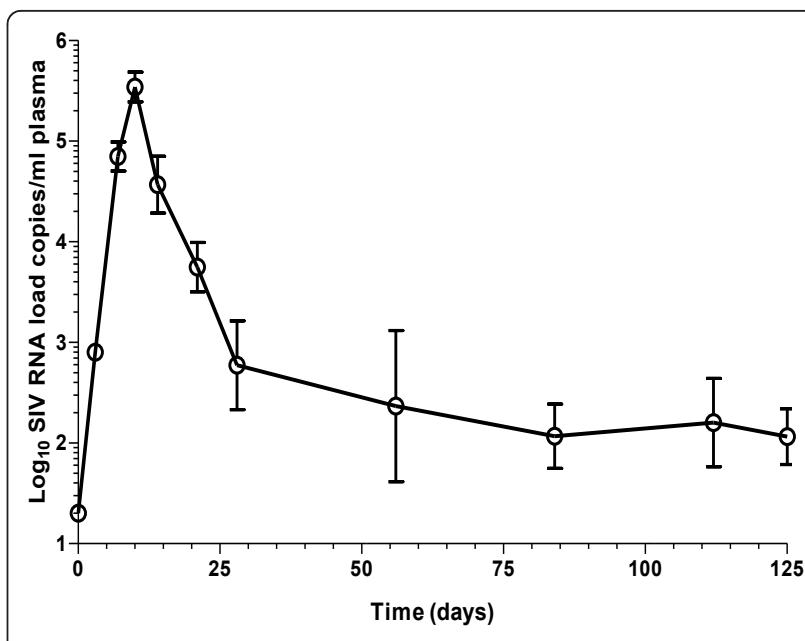

Figure 1 Viral RNA dynamics in macaques vaccinated with attenuated SIV. Following vaccination of cynomolgus macaques $(n=20)$ with live attenuated SIV plasma and lymphoid tissue viral loads was determined at days $0,3,7,10,21$ and 125 post

inoculation. Mean attenuated SIV RNA plasma levels peaked at day 10 with a nadir between days 84 and 125 . For analysis $n=16$ at day 3 reducing to $n=6$ by day 21 as animals were sacrificed, $n=2$ at all time points thereafter. Error bars shown are \pm 1 SEM.

$2.07 \pm 0.32$ and $\log _{10} 2.06 \pm 0.28$, respectively; Figure 1 ). Mean levels of $<1$ SIV DNA copies per 100,000 small intestine (SI) lymphocytes measured at days 3 and 7 contrasted with peak loads at day $10(105 \pm 85)$, but were reduced thereafter at days $21(21 \pm 17)$ and 125 $(2 \pm 1)$. Cell-associated intestinal lymphocytes virus loads were measured at day $10\left(\log _{10} 2.25 \pm 0.75\right.$ SIV producing cells per $10^{6}$ cells), but declined below detection limits by day 21 for all intestinal cell samples (data not shown).

\section{Attenuated SIV does not cause overt depletion of intestinal CD4+ T cells}

Following vaccination with live attenuated SIV, no significant change in the total percentage of $\mathrm{CD} 4+\mathrm{T}$ cells in peripheral blood mononuclear cells (PBMC), peripheral lymph node cells (PLN), mesenteric lymph node cells (MLN) or spleen was observed at days 3, 7, 10, 21 and 125 compared with naïve controls (Figure 2a). It was noted that percentages of CD4+ T cells in peripheral blood fluctuated following vaccination with live attenuated SIV but remained within normal reference range (Figure 2a). Detailed analysis of intra-epithelial lymphocytes (IEL) and lamina propria lymphocytes (LPL) from both the SI and large intestine (LI) did not reveal any significant changes in the total percentage of $\mathrm{CD} 4+\mathrm{T}$ cells following vaccination with live attenuated SIV. A trend towards an increase in the percentage of $\mathrm{CD} 4+\mathrm{T}$ cells over time was noted (Figure $2 \mathrm{~b}$ ). However, this trend was not significant. 


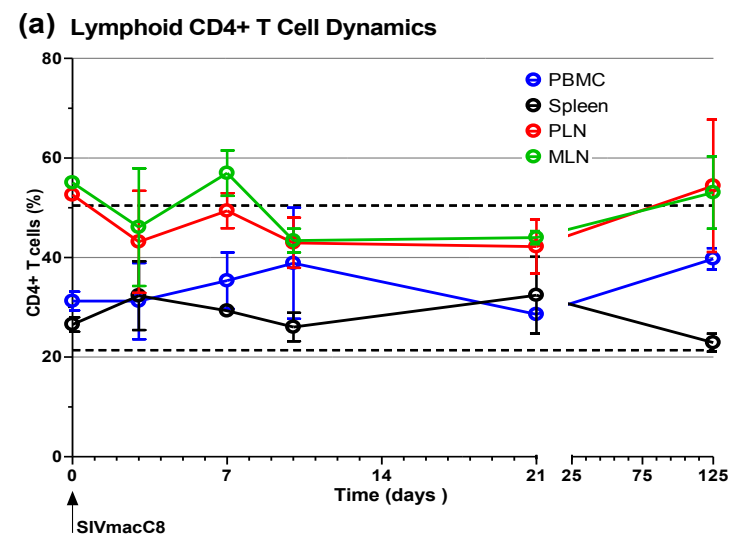

(b) Intestinal CD4+ T Cell Dynamics

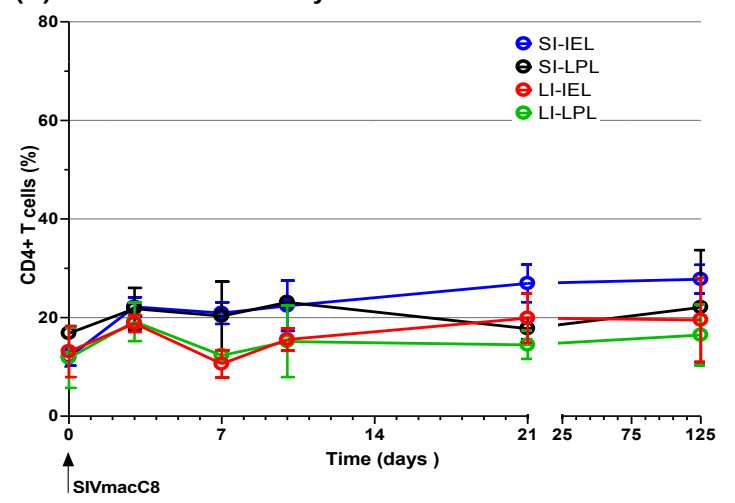

Figure 2 CD4+ $T$ cell dynamics in macaques vaccinated with attenuated SIV. Following vaccination of cynomolgus macaques $(n=20)$ with live attenuated SIV peripheral blood, lymphoid tissue and intestinal lymphocyte CD4+ T cell percentages was determined at days $0,3,7,10,21$ and 125 post inoculation. No evidence of overt CD4+ T cell depletion was detected in peripheral blood, lymphoid tissues (a), or intestinal lamina propria and intraepithelial lymphocytes of the small and large intestine (b). The mean range of CD4+ T cell percentages in peripheral blood derived from 335 naïve cynomolgus macaques \pm 2 standard deviations is $35.9 \% \pm 14.52$, shown as a pair of black dashed lines. For analysis of peripheral blood $n=16$ at day 3 reducing to $n=6$ by day 21 as animals were sacrificed, $\mathrm{n}=2$ at all time points thereafter. For analysis of tissues $\mathrm{n}=4$ at all time points except days 7 and 125 where $\mathrm{n}=2$. Error bars shown are \pm 1 SEM. PBMC: peripheral blood mononuclear cells, PLN: peripheral lymph node, MLN: mesenteric lymph node, SI: small intestine, LI: large intestine, IEL: intraepithelial lymphocytes, LPL: lamina propria lymphocytes.

\section{Attenuated SIV causes dynamic changes in intestinal CD4+CCR5+ T cells}

Analysis of CCR 5 expression by CD4+ T cells focused on memory subsets since naive cells were predominantly CCR5 negative. No significant changes in the proportion of CD4+CCR5+ memory T cells within PBMC, PLN, MLN or spleen were observed following vaccination with live attenuated SIV (Figure 3a). By contrast, vaccination with live attenuated SIV resulted in a marked increase in the mean frequency of all 4 subpopulations of intestinal
CD4+CCR5+ memory $\mathrm{T}$ cells taken together at days 3 $(40.54 \% \pm 6.24 \%, \mathrm{p}<0.05)$ and $7(40.54 \% \pm 7.01 \%, \mathrm{p}$ $<0.05)$ compared with naive controls. The mean level of intestinal CD4+ $\mathrm{T}$ cells positive for CCR5 expression in naive controls was $16.20 \% \pm 2.44 \%$. Remarkably, at day 10 the frequency of intestinal CD $4+$ CCR $5+$ memory $\mathrm{T}$ cells returned to levels observed in naive macaques $(16.45 \% \pm 3.71 \%, \mathrm{p}=0.9)$, apparently wiping out the earlier post vaccination expansion. At day 21 , a small increase in intestinal CD4+CCR5+ memory $\mathrm{T}$ cells $(22.50 \% \pm 2.76 \%, p=0.16)$ was not significant. However, the frequency of this cell population increased significantly at day $125(47.46 \% \pm 5.51 \%, \mathrm{p}<0.05)$, with the caveat that $\mathrm{n}=2$ at this time point. More detailed analysis of increased intestinal CD4+CCR $5+$ memory $\mathrm{T}$ cells at days 3, 7 and 125 revealed that these changes occurred in both the IEL and LPL of the SI and LI (Figure 3b). Representative dot plots showing CCR5 staining of CD4+ PBMC and SI lymphocytes at each time point are shown in Figures 3c and 3d, respectively.

Immunohistochemical analysis of CCR 5 expression by LPL within SI sections of macaques vaccinated with attenuated SIV coincided with the early expansion of intestinal $\mathrm{CD} 4+\mathrm{CCR} 5+\mathrm{T}$ cells seen by flow cytometry at the same time (data not shown). At day 10, a low frequency of CCR5+ LPL was observed by immunohistochemistry (Figure 4) which coincided with flow cytometry data showing depletion of intestinal CD4 $+\mathrm{CCR} 5+\mathrm{T}$ cells at that time. By immunohistochemistry the level of CCR5+ LPL at day 10 was similar to that of naive macaques (data not shown). In contrast, at day 125 the proportion of CCR5+ LPL revealed by immunohistochemistry was greatly increased (Figure 4), coinciding with expansion of intestinal CD4+CCR5+ T cells seen by flow cytometry at that time point.

\section{Attenuated SIV upregulates intestinal CD4+ $T_{C M}$ and $T_{E M}$ cell CCR5 expression}

As in man, macaque $\mathrm{CD} 4+\mathrm{T}$ cell populations can be subdivided into three distinct subpopulations: Naive $\left(\mathrm{T}_{\mathrm{N}}\right)$ which are quiescent and non-dividing, central memory $\left(\mathrm{T}_{\mathrm{CM}}\right)$ and effector memory $\left(\mathrm{T}_{\mathrm{EM}}\right)$ which are distinguished by the absence or presence of immediate effector function, respectively [59]. In cynomolgus macaques these CD4+ $\mathrm{T}$ cell subpopulations can be distinguished using a combination of anti-CD28 and anti-CD95 antibody markers $[59,60]$. Using these we found the intestinal CD4+T cells of naive cynomolgus macaques were almost entirely composed of $\mathrm{CD} 95+\mathrm{CD} 28+\mathrm{T}_{\mathrm{CM}}$ and $\mathrm{CD} 95+\mathrm{CD} 28-\mathrm{T}_{\mathrm{EM}}$ memory cells, with relatively few, approximately $1 \%$, CD95-CD28+ naive $\left(\mathrm{T}_{\mathrm{N}}\right)$ cells present (Figures $5 \mathrm{a}$ and $5 \mathrm{c}$ : day 0 ). Expression of CCR5 was confined primarily to a small fraction of CD4+ $\mathrm{T}_{\mathrm{CM}}$ cells, the $\mathrm{T}_{\mathrm{EM}}$ subset being largely CCR5- (Figures 5b and 5c: day 0 ). Following 


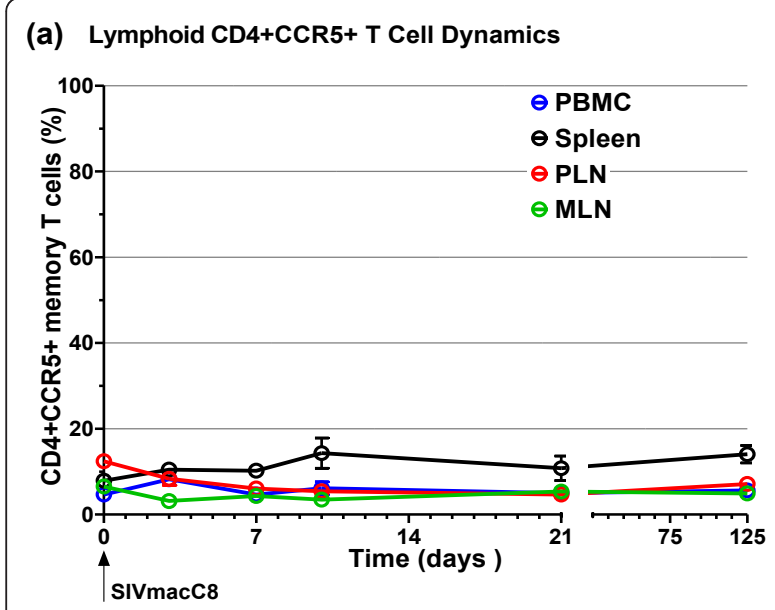

\section{(b) Intestinal CD4+CCR5+ T Cell Dynamics}
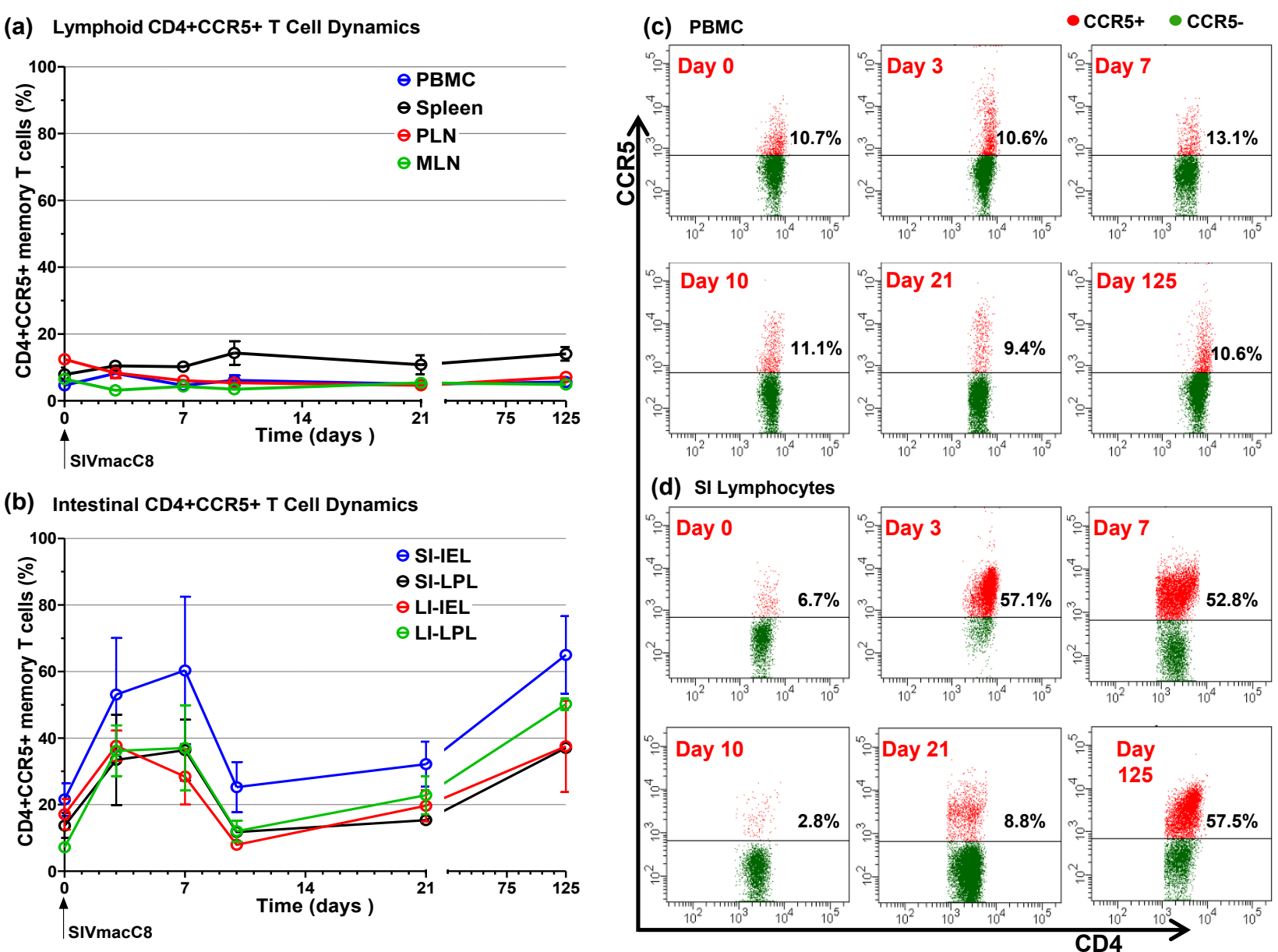

(d) SI Lymphocytes

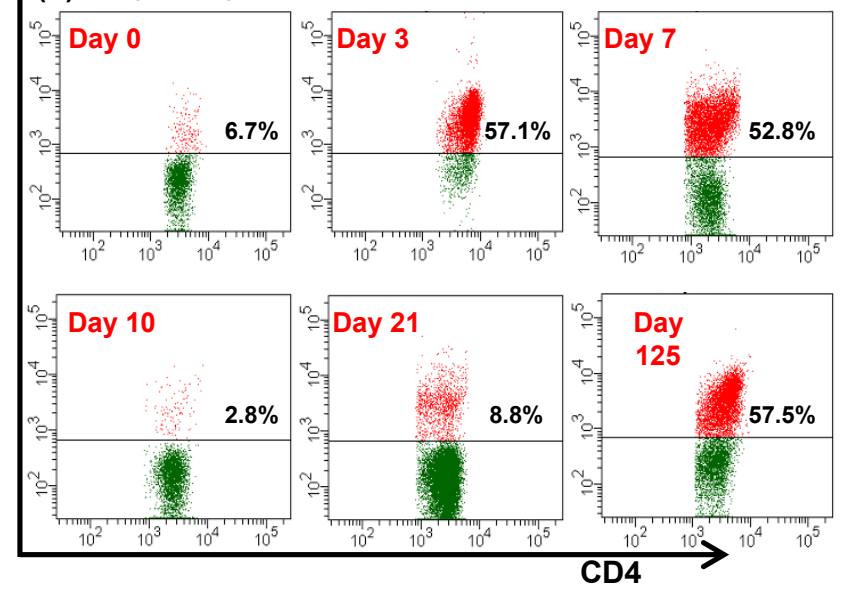

Figure 3 CCR5 + T cell dynamics in macaques vaccinated with attenuated SIV. Following vaccination of cynomolgus macaques $(n=20)$ with live attenuated SIV peripheral blood, lymphoid tissue and intestinal lymphocyte CD4+CCR5+ memory T cell percentages was determined at days $0,3,7,10,21$ and 125 post inoculation. There was no evidence of dynamic changes in percentages of CD4+CCR5+ memory $T$ cell in peripheral blood and lymphoid tissues (a). In contrast, dynamic changes in CD4+CCR5+ memory T cell percentages was observed in the lamina propria and intraepithelial lymphocytes of both the small and large intestine (b). Panels (c) and (d) shows representative staining for CCR5 on CD4+ PBMC and SI lymphocytes, respectively, at each time point. CCR5+CD4+ T cells are shown in red and CCR5-CD4+ T cells in green. For analysis of peripheral blood $n=16$ at day 3 reducing to $n=6$ by day 21 as animals were sacrificed, $n=2$ at all time points thereafter. For analysis of tissues $n=4$ at all time points except days 7 and 125 where $n=2$. Error bars shown are \pm 1 SEM. PBMC: peripheral blood mononuclear cells, PLN: peripheral lymph node, MLN: mesenteric lymph node, SI: small intestine, LI: large intestine, IEL: intraepithelial lymphocytes, LPL: lamina propria lymphocytes.

vaccination with live attenuated SIV, CCR5 expression was upregulated dramatically in both intestinal $\mathrm{CD} 4+\mathrm{T}_{\mathrm{CM}}$ and $\mathrm{T}_{\mathrm{EM}}$ cells at days $3\left(20.23 \% \mathrm{~T}_{\mathrm{CM}} \pm 1.84 \%, \mathrm{p}<0.05\right.$ and $\left.23.03 \% \mathrm{~T}_{\mathrm{EM}} \pm 8.13 \%, \mathrm{p}<0.05\right)$ and $7\left(23.96 \% \mathrm{~T}_{\mathrm{CM}} \pm\right.$ $1.99 \%, \mathrm{p}=0.06$ and $16.25 \% \mathrm{~T}_{\mathrm{EM}} \pm 6.09 \%, \mathrm{p}=0.08$; Figures $5 \mathrm{~b}$ and $5 \mathrm{c})$. However, by day $10 \mathrm{CD} 4+\mathrm{CCR} 5+\mathrm{T}_{\mathrm{CM}}$ and $\mathrm{T}_{\mathrm{EM}}$ cells were reduced significantly compared with day 7 (11.74\% $\mathrm{T}_{\mathrm{CM}} \pm 1.18 \%, \mathrm{p}=0.08$ and $4.28 \% \mathrm{~T}_{\mathrm{EM}} \pm 1.13 \%$, $\mathrm{p}=0.08$ ), the remaining intestinal CD4+ T cells being predominantly CCR5- $\mathrm{T}_{\mathrm{CM}}$ cells due to marked depletion of $\mathrm{T}_{\mathrm{EM}}$ cells (Figures $5 \mathrm{~b}$ and $5 \mathrm{c}$ ). At day 21, a significant increase in the number of intestinal CD4+CCR5- $\mathrm{T}_{\mathrm{N}}$ cells compared with naive controls was observed $(30.9 \% \pm$ $9.3 \%, \mathrm{p}=0.02$; Figures $5 \mathrm{a}$ and $5 \mathrm{c}$ ). Concurrently, restoration of a clearly distinguishable population of CD4+ CD95+CD28- $\mathrm{T}_{\mathrm{EM}}$ cells was observed (Figure 5c). At day 125 elevated numbers of intestinal $\mathrm{T}_{\mathrm{N}}$ remained $(24.9 \% \pm$ $3.1 \%, \mathrm{p}=0.06$ ), but the proportion of $\mathrm{CD} 4+\mathrm{CCR} 5+\mathrm{T}$ cells was now significantly increased, compared to naive controls, $(47.46 \% \pm 5.51 \%, \mathrm{p}<0.05)$ and the CD4+ $\mathrm{T}_{\mathrm{EM}}$ subset was further restored by mostly CCR $5+$ cells (Figures $5 \mathrm{~b}$ and $5 \mathrm{c}$ ).

\section{Attenuated SIV differentially modulates intestinal LPL and IEL CD4+ T cells}

Using the differentiation sequence defined for rhesus macaque CD4+ memory $\mathrm{T}$ cells where CCR7 and then CD28 are sequentially down regulated $[58,59]$, it is 


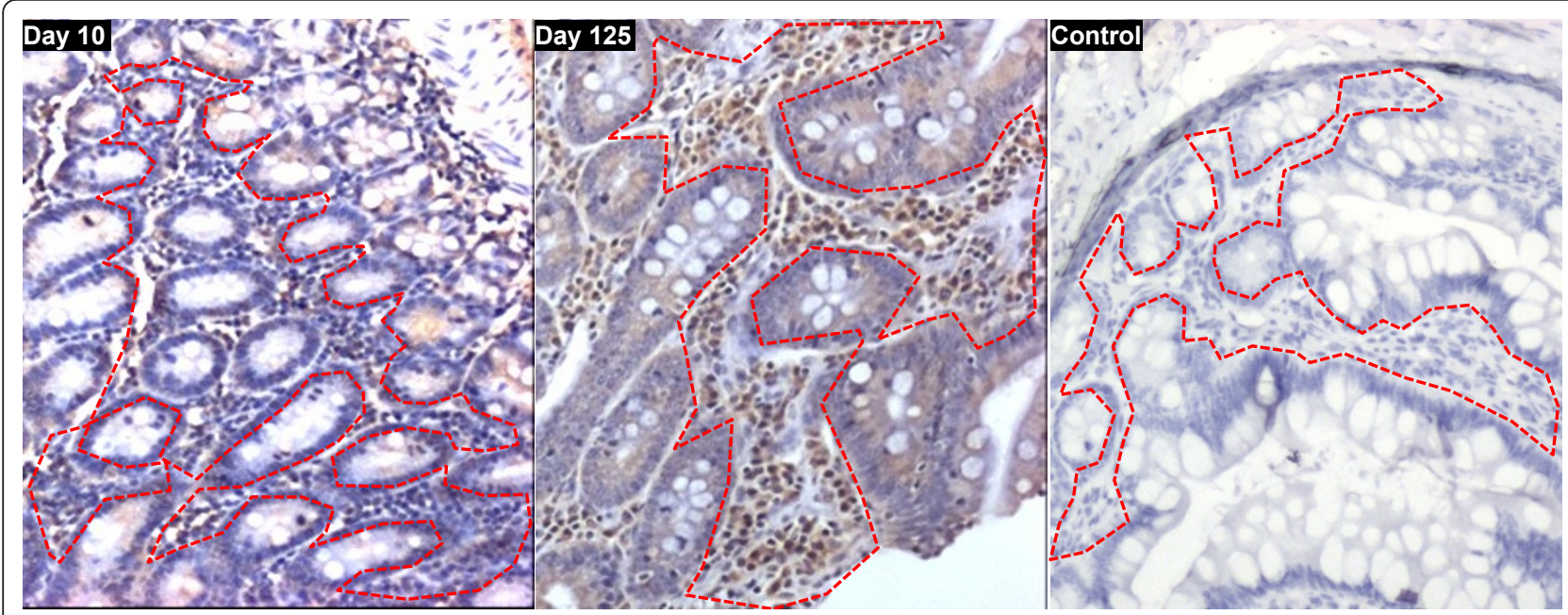

Figure 4 Representative immunohistochemistry showing expression of CCR5 by lamina propria lymphocytes in the small intestine of macaques vaccinated with attenuated SIV. Following vaccination of cynomolgus macaques $(n=20)$ with attenuated SIV

immunohistochemical staining for CCR5+ cells was performed on sections of small intestine. At day 10 (left panel) a low frequency of CCR5+ cells (brown cell surface staining) was observed in the T cell areas of the lamina propria surrounding crypts (delineated by a dashed red line in each panel). In contrast, at day 125 (centre panel) a high frequency of CCR5+ cells was seen in the T cell areas of the lamina propria. The right hand panel shows a control slide with anti-CCR5 antibody omitted. Sections shown are from representative animals, counterstained with haematoxylin. Magnification is $\times 100$.

possible to subdivide cynomolgus macaques CD4+ memory $\mathrm{T}$ cells into 4 subsets, CD28+CCR7 $+\mathrm{T}_{\mathrm{CM}} \rightarrow$ $\mathrm{CD} 28+\mathrm{CCR} 7+\mathrm{T}_{\mathrm{TrM}-1} \rightarrow \mathrm{CD} 28+\mathrm{CCR} 7-\mathrm{T}_{\mathrm{TrM}-2} \rightarrow$ CD28-CCR7- $\mathrm{T}_{\mathrm{EM}}$, where the transitional memory subset-1 $\left(\mathrm{T}_{\mathrm{TrM}-1}\right)$ are essentially CCR5 $+\mathrm{T}_{\mathrm{CM}}$ cells. Using this regimen, we investigated further CCR5 expression by intestinal LPL and IEL CD4+ memory T cells following vaccination with live attenuated SIV. Rather than $\mathrm{T}_{\mathrm{CM}}$ cells, defined previously as CD28+ cells, we found that the majority of intestinal CD4+ memory $\mathrm{T}$ cells in naive cynomolgus macaques were in fact of the transitional memory subset- $2\left(\mathrm{~T}_{\mathrm{TrM}-2}\right)$ and negative for CCR5 expression (Figures 6a, b and 6c). Representative dot plots showing CCR5 staining of SI LPL and IEL CD4+ memory subsets are shown in Figure 6c. Modest frequencies of CCR $5+$ cells were mostly found in the $\mathrm{T}_{\mathrm{TrM}-1}$ subset of LPL and the $\mathrm{T}_{\mathrm{TrM}-2}$ subset of IEL of naive macaques (Figures $6 \mathrm{~b}$ and $6 \mathrm{c}$ ). At day 3 , there was a dramatic increase in CCR 5 expression by both CD4+ $\mathrm{T}_{\mathrm{EM}}$ and $\mathrm{T}_{\mathrm{TrM}-2}$ cells accompanied by a large population shift to a $\mathrm{T}_{\mathrm{EM}}$ cell phenotype, in both LPL and IEL (Figures $6 \mathrm{~b}$ and $6 \mathrm{c}$ ). At the same time $\mathrm{CD} 4+\mathrm{T}_{\mathrm{CM}}$ and $\mathrm{T}_{\mathrm{TrM}-1}$ cells were depleted within LPL and IEL populations (Figures $6 \mathrm{a}$ and $6 \mathrm{c}$ ). At day 7, the majority of LPL and IEL CD4+ $\mathrm{T}_{\mathrm{EM}}$ cells appeared to have either reverted to a $\mathrm{T}_{\mathrm{TrM}-2}$ cell phenotype or were depleted, whilst the remaining CD4+ $\mathrm{T}_{\mathrm{TrM}-2}$ cells were largely positive for CCR5 expression (Figures $6 \mathrm{~b}$ and $6 \mathrm{c}$ ). Very few LPL and IEL CD4+ $\mathrm{T}_{\mathrm{CM}}$ and $\mathrm{T}_{\mathrm{TrM}-1}$ cells were detected at day 7 and at all time points investigated thereafter (Figures 6a and 6c). At day 10, CCR5 expression within the $\mathrm{CD} 4+\mathrm{T}_{\mathrm{EM}}$ and $\mathrm{T}_{\mathrm{TrM}-2}$ subsets, within LPL and IEL, was almost completely lost (Figures $6 \mathrm{~b}$ and $6 \mathrm{c})$. The remaining LPL and IEL CD4+ $\mathrm{T}_{\mathrm{EM}}$ and $\mathrm{T}_{\mathrm{TrM}-2}$ cells were largely negative for CCR 5 expression (Figures $6 \mathrm{~b}$ and $6 \mathrm{c}$ ). At day 21, a higher frequency of IEL CD4+CCR5+ $\mathrm{T}_{\mathrm{EM}}$ cells was observed, but no marked increase was seen in the frequency of LPL CD4+ CCR5 $+\mathrm{T}$ cells (Figures $6 \mathrm{~b}$ and $6 \mathrm{c}$ ). At day 125, the proportion of IEL CD4+CCR5 $+\mathrm{T}_{\mathrm{EM}}$ cells increased further although $\mathrm{T}_{\mathrm{TrM}-2}$ cells were largely CCR5- (Figures $6 \mathrm{~b}$ and $6 \mathrm{c}$ ). By contrast, the frequency of LPL CD4+ $\mathrm{T}_{\mathrm{EM}}$ cells was greatly reduced and $\mathrm{T}_{\mathrm{TrM}-2}$ cells increased at day 125 (Figure 6a). Marked increases in the frequency of LPL CD4+CCR5+ cells at day 125 were mostly confined to the $\mathrm{T}_{\mathrm{TrM}-2}$ subset (Figures $6 \mathrm{~b}$ and $6 \mathrm{c}$ ), further distinguishing it from the IEL compartment at this time.

\section{Discussion}

Live attenuated SIV vaccines provide potent protection, but the detailed properties of this protection appear to vary depending upon the model system studied. In this report, we describe further studies to characterise the mechanism of protection conferred by a minimally nefdeleted attenuated vaccine derived from SIVmac251, called SIVmacC8 [61], in (Mauritian derived) cynomolgus macaques. Vaccination of cynomolgus macaques with SIVmacC8 protects against infection with virus infected cells as well as cell free virus [5], develop by 3 weeks [43] and paradoxically protects against a 


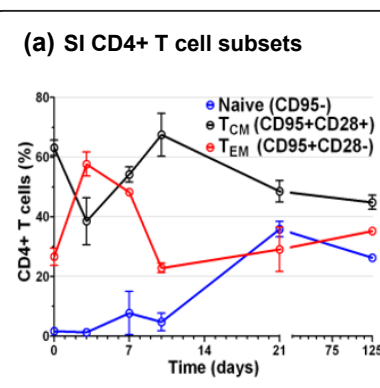

(b) SI CCR5 expression

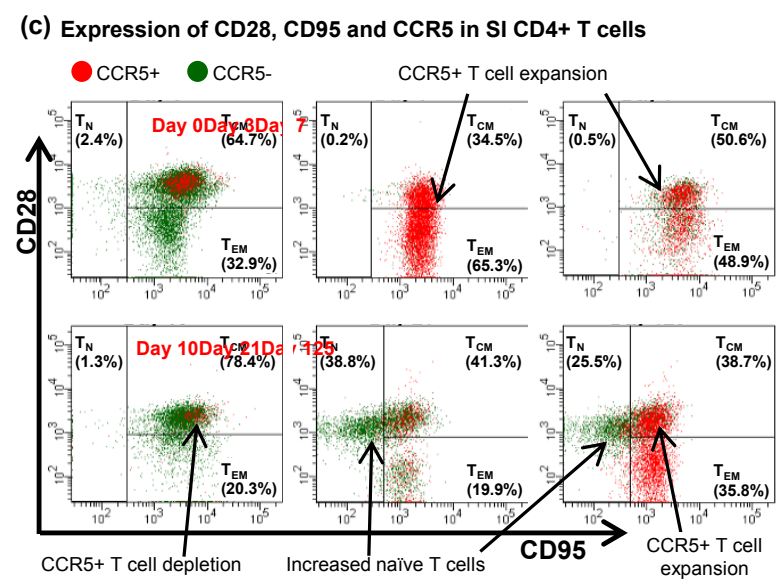

Figure $5 \mathrm{CD} 4+C \mathrm{CR} 5+\mathrm{T}_{\mathrm{CM}}$ and $\mathrm{T}_{\mathrm{EM}}$ cell dynamics in the small intestine of macaques vaccinated with attenuated SIV.

Following vaccination of cynomolgus macaques $(n=20)$ with live attenuated SIV the percentages of CD4+CCR5 $+T_{C M}$ and $T_{E M}$ cells from the SI was determined at days 0, 3, 7, 10, 21 and 125 post inoculation. Dynamic changes in the frequency of SI CD4+ lymphocytes naïve, $T_{C M}, T_{E M}$ subsets was observed following vaccination (a). Increases in the percentage of $C D 4+C C R 5+T_{C M}$ and $T_{E M}$ cells was observed at days 3 and 7, reversed at days 10 and 21, then increased again at day 125 compared to naive controls (b). Immunostaining of SI lymphocytes gated on CD3+CD4+ T cells from one representative animal from each time point are shown (c) In each panel the left hand quadrant shows CD28+CD95- $T_{N}$ cells, the upper right quadrant CD28+CD95+ $T_{C M}$ cells and the lower right quadrant $C D 28-C D 95+T_{E M}$ cells. Percentages shown give the proportion present in each of these subsets. CD4+CCR5+ T cells are shown in red and CD4+CCR5- $T$ cells in green. $T_{N}$ : naive, $T_{C M}$ : central memory, TEM$_{\text {: }}$ effector memory, SI: small intestine.

genetically heterologous virus challenge better (N. Berry personal communication) than a highly vigorous homologous virus challenge [37]. Since we have been unable to identify a mechanism of protection amongst adaptive immune responses that develop following vaccination, either by passive transfer of immune serum [24] or CD8 $+\mathrm{T}$ cell depletion $[34,62]$, we investigated whether other responses to vaccination may contribute to protection. It is accepted that infection with wild-type SIV rapidly induces a depletion of CD4+CCR5+ memory $\mathrm{T}$ cells in the GALT [54-57]. Therefore, we speculated whether a similar effect following vaccination with SIVmacC8 would result in target cell depletion, preventing subsequent virus challenges from infecting the GALT and so preventing a systemic infection from being established. The data indicate that, following inoculation of SIVmacC8, marked dynamic changes in $\mathrm{CD} 4+\mathrm{T}$ cell populations occur that may not only contribute to the protective effect of vaccination, but could also be instrumental in regulating the kinetics of replication by this virus.

Previous reports of $\mathrm{T}$ cell dynamics in the GALT of rhesus macaques, following infection with attenuated SIV, suggested that minimal changes occurred since the total CD4+population remained unaltered $[48,58]$. This also appeared to be the case for cynomolgus macaques vaccinated with SIVmacC8. However, more detailed analyses of $\mathrm{CD} 4+\mathrm{CCR} 5+$ memory $\mathrm{T}$ cell populations revealed a more dynamic picture of events.

By immunostaining with antibodies to CD3, CD4, CCR5, CD28, CD95 and CCR7 markers, it was possible to define the naive and memory helper $\mathrm{T}$ cell compartments in considerable detail. Prior to vaccination with SIVmacC8, the low level of CCR5 expression by CD4+ $\mathrm{T}_{\mathrm{EM}}$ cells in naive cynomolgus macaques would be anticipated with a lack of activation and proinflammatory Th1 responses [63-65]. By contrast, within 3 days of vaccination when the primary viraemia is first detectable, a dramatic expansion of intestinal CD4+CCR5+ $\mathrm{T}_{\mathrm{EM}}$ cells was detected, consistent with an acute Th1 proinflammatory response [66-68]. This expansion of intestinal CD4+CCR5+ $\mathrm{T}_{\mathrm{EM}}$ cells was probably a result of activation-associated upregulation of CCR 5 expression by CD4+CCR5- T cells, since concurrent reductions in less differentiated CD4+ $\mathrm{T}_{\mathrm{CM}}, \mathrm{T}_{\mathrm{TrM}-1}$ and $\mathrm{T}_{\mathrm{TrM}-2}$ cells were detected. Alternative explanations such as the proliferation of intestinal CD4+CCR5 $+\mathrm{T}_{\mathrm{EM}}$ cells or an influx of CD4+CCR5+ $\mathrm{T}_{\mathrm{EM}}$ cells into the intestinal mucosa are less likely because of the limited proliferative potential of $\mathrm{T}_{\mathrm{EM}}$ cells [69] or the need for co-ordinated outflow of CD4+CCR5- T cells to balance overall CD4+ T cell percentages.

The marked expansion in the activated intestinal CD4+ CCR5 + cell population in the absence of acquired immune responses would provide large numbers of target cells in which SIVmacC8 could replicate readily. Indeed, virus infected cells are detectable in the small intestine from day 3 by immunohistochemistry (D. Ferguson personal communication). However, it is not known whether this series of events reflects SIV exploiting a generic host response to infection or whether it is a result of specific viral factors driving events. Nevertheless, not only did the early expansion of intestinal CD4+CCR $5+\mathrm{T}$ cells, detectable from day 3, appear to "fuel" the increases in plasma SIV RNA loads at days 3 and 7, but also the loss of LPL and IEL CD4+CCR5+ $\mathrm{T}_{\mathrm{EM}}$ cells from day 7 also augured the end of the primary viraemia from day 10 when there 


\section{(a) SI CD4+CD95+ T cell subsetsSI CC(Rt) expression}

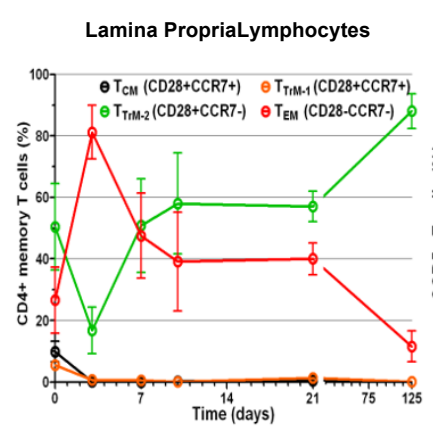

Intraepithelial Lymphocytes

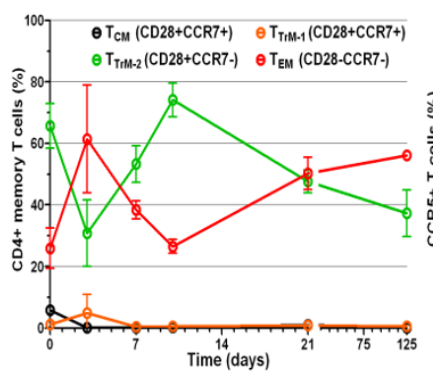

Lamina PropriaLymphocytes

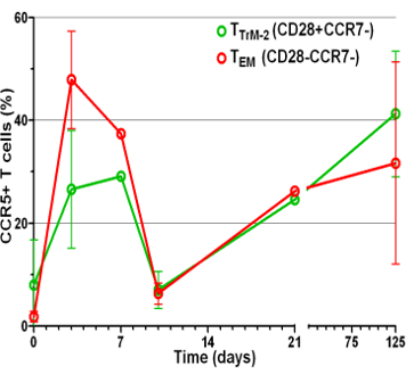

Intraepithelial Lymphocytes

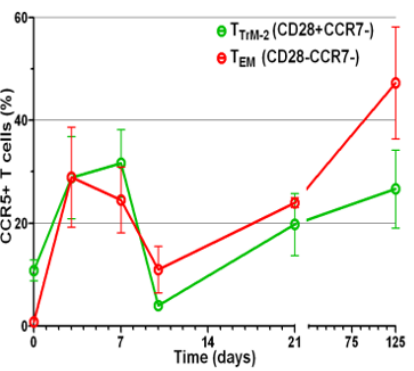

(c) Expression of CCR7,CCR5 and CD28 in SI CD4+CD95+ T cells

Lamina PropriaLymphocytes

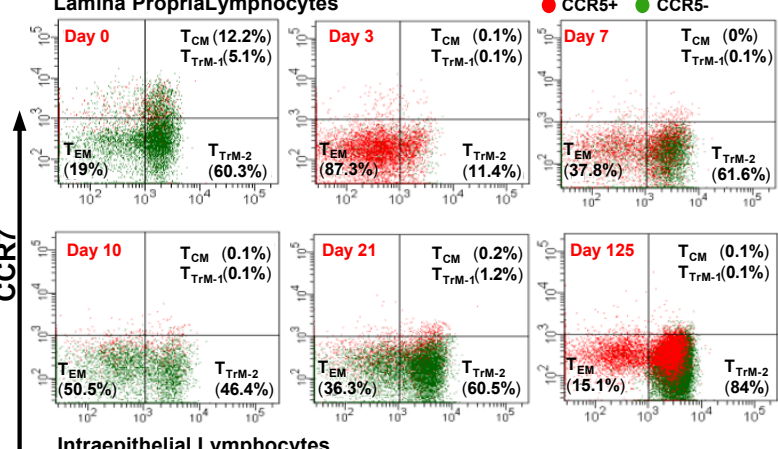

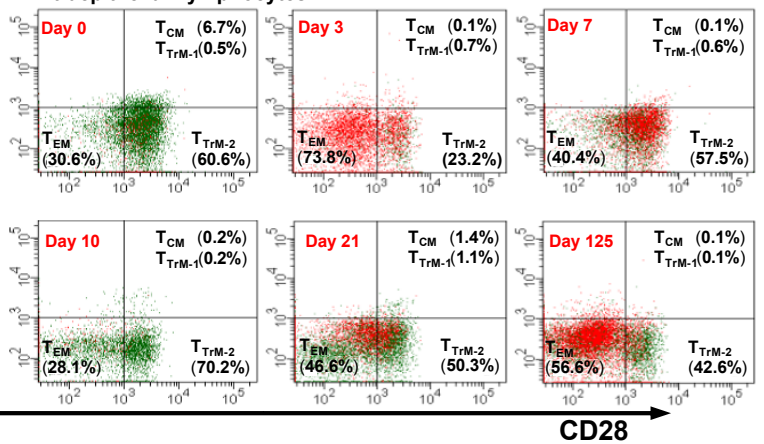

Figure 6 Vaccination with attenuated SIV differentially modulates LPL and IEL CD4+CCR5+ T cell memory subsets. Following vaccination of cynomolgus macaques $(n=20)$ with live attenuated SIV the percentages of LPL and IEL CD4+CCR5+ $T_{C M}, T_{T r M-1}, T_{T r M-2}$ and $T_{E M}$ cells from the SI was determined at days $0,3,7,10,21$ and 125 post inoculation. Transient increases in the percentage of SI LPL and IEL CD4+ $T_{E M}$ cells with a concomitant decrease in CD4+ $T_{\text {TrM-2 }}$ cells was observed at day 3 (a). Increased percentages of SI LPL and IEL CD4+CCR5+ $T_{T r M-2}$ and $T_{E M}$ cells was observed at days 3 and 7 (b). Immunostaining of small intestine LPL and IEL gated on CD3+CD4+CD95+ memory T cells from one representative animal from each time point are shown (c). In each panel the upper right hand quadrant shows CD28+CCR7+ $T_{C M}$ and $T_{\text {TrM }}-1$ cells, the lower right quadrant CD28+CCR7- $T_{\text {TrM-2 }}$ cells and the lower left quadrant CD28-CCR7- $T_{\text {EM }}$ cells. CD4+ $T_{\text {TrM-1 }}$ cells are essentially CCR5+ $T_{C M}$ cells. Percentages shown give the proportion present in each of these subsets. CD4+CD95+CCR5+ T cells are shown in red and CD4+CD95+ CCR5- $T$ cells in green. $T_{\text {СM: }}$ central memory, $T_{\text {TrM-1 }}$ : transitional memory subset-1, $T_{\text {TrM-2: }}$ transitional memory subset-2, $T_{E M}$ : effector memory, IEL: intraepithelial lymphocytes, LPL: Iamina propria lymphocytes, SI: small intestine.

were dramatic reductions in remaining LPL and IEL CD4 + CCR5 $+\mathrm{T}_{\mathrm{TrM}-2}$ cells to pre-infection levels. These data, which were virtually indistinguishable from those previously reported for this virus [70], suggest that the kinetics of SIVmacC8 primary viraemia may be regulated by the availability of target cells as much as the development of anti-viral immune responses. Studies of the infection of Chinese rhesus macaques with pathogenic SIV have also reported that peak plasma SIV RNA loads were associated with the loss of intestinal CD4+CCR5+ T cells $[71,72]$. Nevertheless there is considerable evidence that acquired anti-SIV immune responses, such as CD8+ cytotoxic T cells, regulate viral loads [33,34,73-76]. Intriguingly, in a previous report of the primary viraemia of SIVmacC8 during profound CD8+ cell depletion, whilst the peak SIV RNA loads were approximately 300 times higher in the absence of CD8+ T cells, SIV RNA loads declined prior to recovery of detectable CD8+ T cells [34], indicating that other mechanisms must also contribute to the control of the primary viraemia.
The dramatic loss of intestinal CD4+CCR5+ T cells between days 7 and 10, post vaccination with attenuated SIV, may be due to indirect mechanisms such as CD95 dependant apoptosis [56] as well as direct lytic viral replication. However, it is unclear why overall CD4+ $\mathrm{T}$ cell percentages were not then reduced, as per wildtype SIV infection $[48,58]$. It may be that lower cellassociated virus loads and the non-pathogenic nature of attenuated SIV infection reduce rates of CD4+CCR5+ $\mathrm{T}$ cell attrition thereby allowing $\mathrm{T}$ cell homeostatic repopulation of the GALT to be sustained. Such repopulation could originate from outside the GALT or through expansion of intestinal CD4+CCR5- $\mathrm{T}_{\mathrm{EM}}$ and $\mathrm{T}_{\mathrm{TrM}-2}$ cell populations. Though at this time there were few naive $T_{N}$ cells detectable to suggest repopulation, and $\mathrm{T}_{\mathrm{EM}}$ cells have been reported to have limited proliferative capacity $[77,78]$; however, the high proliferative capacity of CD4+ $\mathrm{T}_{\mathrm{TrM}-2}$ [59] cells could have been able to support that repopulation. Alternatively, down regulation of CCR5 expression on CD4+CCR5+ T cells may 
better account for the dynamic changes observed between days 7 and 10, that is not necessarily due to depletion. In order to address this possibility we need to investigate whether CD4+CCR5- cells harbour attenuated SIV, as others have found with pathogenic SIV [57].

Nevertheless, at days 21 and 125, there was a dramatic increase in intestinal $T_{N}$ cells that may signify an influx of repopulating cells to replace ongoing losses and maintain homeostasis, as has been reported following infection with pathogenic SIV [48]. Since the second dramatic increase in CD4+CCR5+ intestinal $\mathrm{T}$ cells at day 125 occurred without the appearance of increased SIV RNA loads, other factors not present during the acute infection must be restricting SIV replication, preventing further loss of intestinal CD4+CCR5+ T cells. Further work is needed to determine whether adaptive immune or other anti-viral responses, such as retroviral superinfection resistance, are involved at these later times specifically [79]. Whatever the mechanism identified, it needs to be able to account for the characterised properties of protection conferred by live attenuated vaccines in the species of macaque being studied.

One of the difficulties for understanding vaccine protection conferred by live attenuated SIV has been the frequently confusing, if not conflicting data, obtained by different groups using related vaccine models but in different species of macaque. In this report, we found a much lower frequencies of intestinal CD4+CCR5+ T cells $(16.16 \% \pm 2.44 \%)$ in naive cynomolgus macaques compared with Indian rhesus macaques, where the level of CCR 5 expression by CD4+ intestinal T cells is reported to be $>60 \%$ [57]. Intriguingly, average levels of CCR5 expression on CD4+ intestinal T cells of SIV natural hosts is reported to be considerably lower those we have described. For example, 9.13\% for African green monkeys and $1.2 \%$ for sooty mangabeys [80]. It may be hypothesised that this lower level of CCR 5 expression by CD4+ T cells may contribute to the more limited damage of the immune system caused by wild-type SIV in these hosts as there would be reduced numbers of target cells susceptible to infection and destruction at any time [80]. Conversely, the higher levels of CCR5 expression on peripheral $\mathrm{CD} 4+\mathrm{T}$ cells of Indian versus Chinese rhesus macaques, $21.8 \% \pm 7.7 \%$ and $6.7 \% \pm 4.6 \%$ respectively, could contribute to the sustained high virus load and faster disease progression seen in Indian rhesus macaques infected with SIV $[72,81]$. If alterations in the frequency of these same CD4+ $\mathrm{T}$ cell subsets contribute not only to viral kinetics but also to the protection mediated by live attenuated SIV, then it may be anticipated that undertaking a similar vaccine study in macaques of different species could result in distinct outcomes.

\section{Conclusions}

Vaccination with live attenuated SIV causes dynamic changes and chronic expansion of CD4+CCR5+ intestinal $\mathrm{T}$ cell memory subsets, more consistent with immune activation than target cell depletion. The profile of high frequencies of CD4+CCR5+ T cells detectable in the GALT after vaccination is not identical to those found in naive animals or expanded during the early stages of the primary viraemia, implying lasting immune modulation. Understanding the impact of the immune modulation caused by attenuated SIV and the mechanism(s) involved may provide insight into the development of novel vaccine approaches or therapies that safely reproduce this protection.

\section{Methods}

\section{Experimental Outline}

In this study, twenty D-type-retrovirus-free juvenile cynomolgus macaques (Macaca fascicularis), housed and maintained in accordance with UK Home Office guidelines for the care and maintenance of nonhuman primates, were used. Animals were sedated with ketamine hydrochloride before inoculation of virus or venepuncture and killed humanely by an overdose of anaesthetic. The vaccine virus SIVmacC8 is a clone of a rhesus passage of wild-type SIVmac251 [8] attenuated by a $12 \mathrm{bp}$ in-frame deletion in the nef open reading frame and two further conservative amino acid changes [61]. Cynomolgus macaques were inoculated with vaccine virus by intravenous injection of $5000 \mathrm{TCID}_{50}$ of the $9 / 90$ pool of SIVmacC8 [61], which has an end-point titre of $10^{4}$ $\mathrm{TCID}_{50} / \mathrm{ml}$ on C8166 cells, and were sacrificed in pairs on days $3,7,10,21$ and $125(\mathrm{n}=2)$ in the first study and days 3,10 and $21(\mathrm{n}=2)$ in a second study for analysis and comparison with naive macaques $(n=4)$ of CCR5 expression across CD4+ T cell memory subsets.

\section{Tissue collection}

PBMCs were isolated by density gradient centrifugation as previously described [34]. Spleen, PLN and MLN cells were isolated by mechanical tissue disaggregation (Medimachine, BD Biosciences, Oxford, UK). LPL and IEL were isolated from the SI and LI. Briefly, intestinal sections were opened longitudinally, cut into $5 \mathrm{~cm}$ segments and washed with cold HBSS (Gibco ${ }^{\mathbb{B}}$ Invitrogen Ltd., Paisley, UK). Segments were then incubated in cold $\mathrm{Ca}^{2+}$ and $\mathrm{Mg}^{2+}$ free HBSS (Gibco ${ }^{\circledR}$ Invitrogen Ltd., Paisley, UK) containing $10 \mathrm{mM}$ Dithiothreitol (SigmaAldrich, Dorset, UK) on an orbital shaker for 45-60 minutes at $4{ }^{\circ} \mathrm{C}$. After incubation IEL were collected as the filtrate from a $100 \mu \mathrm{m}$ cell strainer (BD Biosciences, Oxford, UK). Remaining intestinal tissue was then incubated with warm collagenase solution $(0.5 \mathrm{mg} / \mathrm{ml})$ on an orbital shaker at $37^{\circ} \mathrm{C}$ for $30-45$ minutes. After incubation LPL were collected as the filtrate from a $100 \mu \mathrm{m}$ 
cell strainer (BD Biosciences, Oxford, UK). All extracted filtrates were centrifuged at $400 \mathrm{~g}$ for $10 \mathrm{~min}$, pellets resuspended in RPMI 1640 (Sigma-Aldrich, Dorset, UK), layered onto FCS and spun at $400 \mathrm{~g}$ for $10 \mathrm{~min}$. Cell pellets were re-suspended in RPMI 1640 containing 2 $\mathrm{mg} / \mathrm{ml}$ DNAse (Sigma-Aldrich, Dorset, UK) and incubated for $20 \mathrm{~min}$ on shaker at $37^{\circ} \mathrm{C}$. Cell suspensions were layered over a 35\% Percoll gradient (SigmaAldrich, Dorset, UK) which was layered over a $65 \%$ Percoll gradient and centrifuged at $500 \mathrm{~g}$ for $30 \mathrm{~min}$. Lymphocytes present at the interface between the $35 \%$ and 65\% Percoll layers were aspirated and cells washed twice in RPMI 1640. Prior to staining cells were further processed using a "Dead Cell Removal Kit", according to manufacturer's instructions, to reduce debris (Miltenyi Biotec, Surrey, UK).

\section{Detection and quantification of SIV RNA, DNA and cell- associated virus}

SIV RNA levels in plasma were determined by quantitative real-time RT-PCR (qRT-PCR) as previously described [37]. Viral RNA was extracted from $140 \mu \mathrm{l}$ plasma using viral RNA mini-kits (QIAamp; Qiagen, Crawley, UK) then eluted in a total volume of $50 \mu \mathrm{l}$ AVE buffer. RNA $(5 \mu \mathrm{l})$ extracted from reference or experimental samples were amplified in triplicate using the Brilliant QRT-PCR plus Core Reagents one-step kit (Agilent Technologies Inc., CA, USA). Oligonucleotide primers and probe sequences, located in conserved regions of gag, were optimized at 300 and $100 \mathrm{nM}$ respectively [37]. A value of $1.3 \log 10$ SIV RNA copies per $\mathrm{ml}$ is below the cut-off for quantification in this assay. Cellassociated virus loads of isolated lymphoid cells were determined by co-culture with C8166 cells, and the presence of replicating virus was confirmed by syncytia identification or by antigen capture at 28 days [62].

Genomic DNA was extracted from $10^{6}$ purified intestinal lymphocytes (as described above) and proviral SIV gag DNA levels determined by quantitative PCR (qPCR), using the same primer/probe sequences as the qRT-PCR assay [37]. The concentration added to each PCR assay was determined retrospectively using a fluorometic DNA quantification kit (Sigma-Aldrich, Dorset, UK) in a microtitre format. Aliquots of DNA $(1 \mu \mathrm{l})$ were assayed in triplicate using a Taqman Universal PCR Master Mix (ABI) against a standard curve of the p2-LTR plasmid [70] serially diluted in herring sperm DNA [37]. SIV DNA levels were expressed as copies of SIV DNA per $10^{5}$ mononuclear cells (MNC) with an absolute limit of detection being 1 SIV DNA copy per $10^{5}$ cells.

Analysis of CCR5 expression by T cell memory subsets Expression of CCR 5 within $\mathrm{T}$ cell subsets defined by CD3FITC (clone FN18, AbD Serotec, UK), CD4-APC-Cy7 (clone OKT4, Biolegend, Cambridge, UK), CD8-AmCyan (clone SK1, BD Biosciences, Oxford, UK), CD28-PerCPCy5.5 (clone CD28.2, eBioscience Ltd., Hatfield, UK), CD95-PE-Cy7 (clone DX2, eBioscience Ltd., Hatfield, UK) and CCR7-FITC (clone 150503, R\&D systems, Abingdon, UK) was assessed by flow cytometry. Within the CD3+ CD4+ (helper) $\mathrm{T}$ cell subset, naive (CD95-CD28+, $\mathrm{T}_{\mathrm{N}}$ ), central memory (CD95+CD28+ or CD95+CD28+CCR7+ CCR5-, $\mathrm{T}_{\mathrm{CM}}$ ), transitional memory subset-1 (CD95+ CD28+CCR7+CCR5+, $\left.\mathrm{T}_{\text {TrM-1 }}\right)$, transitional memory subset-2 (CD95+CD28+CCR7-, $\left.\mathrm{T}_{\mathrm{TrM}-2}\right)$ and effector memory (CD95+CD28- or CD95+CD28-CCR7-, $\mathrm{T}_{\mathrm{EM}}$ ) distinctions were made $[59,60]$. Staining was performed as previously described [29]. Acquisition was performed using a BD FACSCanto II and analysed using BD FACSDiva software (BD Biosciences, Oxford, UK). At least 10,000 CD3+CD4+ events were collected for subset analysis.

Immunohistochemical analysis was performed as previously described [82]. Briefly formaldehyde fixed, paraffin embedded tissue sections were de-waxed, and re-hydrated before being incubated with $50 \mu \mathrm{g} / \mathrm{ml}$ proteinase K (Roche Products Ltd., Welwyn Garden City, UK) in $\mathrm{PBS}$ pH7.4 for 15 minutes at $37^{\circ} \mathrm{C}$ to unmask target antigens followed by immuno-labelling with anti-CCR5 (3A9, BD Biosciences, Oxford, UK). Bound antibodies were visualized using the Vector ABC amplification system (Vector Laboratories, Peterborough, UK) in combination with a biotinylated universal anti-mouse/rabbit secondary antibody (Vector Laboratories, Peterborough, UK).

\section{Statistical analysis}

A Kruskal-Wallis test followed by Dunn's post test was used for comparison of CD3+CD4+ and CD3+CD4 + CCR5+ counts and plasma SIV vRNA loads at each time point measured. Values expressed are mean \pm standard error of means (SEM). All reported P values were two sided at the 0.05 significance level determined using Prism 5 software (Graph Pad Software, CA, USA).

\section{Acknowledgements}

We thank the technical and veterinary staff at NIBSC for animal care. This work was funded by MRC grant G0600007.

\section{Author details}

${ }^{1}$ Biotherapeutics Group, National Institute of Biological Standards and Control/Health Protection Agency, Potters Bar, Hertfordshire, UK. ${ }^{2}$ Division of Retrovirology, National Institute of Biological Standards and Control/Health Protection Agency, Potters Bar, Hertfordshire, UK.

\section{Authors' contributions}

$\mathrm{RS}, \mathrm{NA}$ and NB conceived and designed the experiments; $\mathrm{BL}, \mathrm{CH}, \mathrm{DF}, \mathrm{DS}, \mathrm{JH}$, $M P, R Q, M R$ and WE performed the experiments; $R S$ and $B L$ analysed the data; RS, BL and NA wrote the paper. All authors read and approved the final manuscript.

\section{Competing interests}

The authors declare that they have no competing interests. 
Received: 4 November 2010 Accepted: 3 February 2011

Published: 3 February 2011

\section{References}

1. Desrosiers RC, Wyand MS, Kodama T, Ringler DJ, Arthur LO, Sehgal PK, Letvin NL, King NW, Daniel MD: Vaccine protection against simian immunodeficiency virus infection. Proc Natl Acad Sci USA 1989, 86:6353-6357.

2. Hu SL, Zarling JM, Chinn J, Travis BM, Moran PA, Sias J, Kuller L, Morton WR, Heidecker G, Benveniste RE: Protection of macaques against simian AIDS by immunization with a recombinant vaccinia virus expressing the envelope glycoproteins of simian type D retrovirus. Proc Natl Acad Sci USA 1989, 86:7213-7217.

3. Stott EJ, Almond N, Kent K, Walker B, Hull R, Rose J, Silvera P, Sangster R, Corcoran T, Lines J, Silvera K, Luciw P, Murphy-Corb M, Momin P, Bruck C: Evaluation of a candidate human immunodeficiency virus type 1 (HIV-1) vaccine in macaques: effect of vaccination with HIV-1 gp120 on subsequent challenge with heterologous simian immunodeficiency virus-HIV-1 chimeric virus. J Gen Virol 1998, 79:423-432.

4. Hanke T, Samuel RV, Blanchard TJ, Neumann VC, Allen TM, Boyson JE, Sharpe SA, Cook N, Smith GL, Watkins DI, Cranage MP, McMichael AJ: Effective induction of simian immunodeficiency virus-specific cytotoxic $T$ lymphocytes in macaques by using a multiepitope gene and DNA prime-modified vaccinia virus Ankara boost vaccination regimen. I Virol 1999, 73:7524-7532.

5. Berry N, Stebbings R, Brown S, Christian P, Thorstensson R, Ahmed RK, Davis L, Ferguson D, D'Arcy N, Elsley W, Hull R, Lines J, Wade-Evans A, Stott J, Almond N: Immunological responses and viral modulatory effects of vaccination with recombinant modified vaccinia virus Ankara (rMVA) expressing structural and regulatory transgenes of simian immunodeficiency virus (SIVmac32H/J5M). J Med Primatol 2007, 36:80-94.

6. Barnett SW, Burke B, Sun Y, Kan E, Legg H, Lian Y, Bost K, Zhou F, Goodsell A, Zur Megede J, Polo J, Donnelly J, Ulmer J, Otten GR, Miller CJ, Vajdy M, Srivastava IK: Antibody-mediated protection against mucosal simian-human immunodeficiency virus challenge of macaques immunized with alphavirus replicon particles and boosted with trimeric envelope glycoprotein in MF59 adjuvant. J Virol 2010, 84:5975-5985.

7. Daniel MD, Kirchhoff F, Czajak SC, Sehgal PK, Desrosiers RC: Protective effects of a live attenuated SIV vaccine with a deletion in the nef gene. Science 1992, 258:1938-1941.

8. Almond N, Kent K, Cranage M, Rud E, Clarke B, Stott EJ: Protection by attenuated simian immunodeficiency virus in macaques against challenge with virus-infected cells. Lancet 1995, 345:1342-1344.

9. Bogers WM, Niphuis H, Ten Haaft P, Laman JD, Koornstra W, Heeney JL: Protection from HIV-1 envelope-bearing chimeric simian immunodeficiency virus (SHIV) in rhesus macaques infected with attenuated SIV: consequences of challenge. AIDS 1995, 9:F13-F18.

10. Dunn CS, Hurtrel B, Beyer C, Gloeckler L, Ledger TN, Moog C, Kieny MP, Mehtali M, Schmitt D, Gut JP, Kirn A, Aubertin AM: Pathogenicity of live, attenuated SIV after mucosal infection of neonatal macaques.

11. Shibata R, Siemon C, Czajak SC, Desrosiers RC, Martin MA : Live, attenuated simian immunodeficiency virus vaccines elicit potent resistance against a challenge with a human immunodeficiency virus type 1 chimeric virus. J Virol 1997, 71:8141-8148.

12. Nilsson C, Mäkitalo B, Thorstensson R, Norley S, Binninger-Schinzel D, Cranage M, Rud E, Biberfeld G, Putkonen P: Live attenuated simian immunodeficiency virus (SIV)mac in macaques can induce protection against mucosal infection with SIVsm. AIDS 1998, 12:2261-2270.

13. Wyand MS, Manson K, Montefiori DC, Lifson JD, Johnson RP, Desrosiers RC Protection by live, attenuated simian immunodeficiency virus against heterologous challenge. J Virol 1999, 73:8356-8363.

14. Kumar A, Mukherjee S, Shen J, Buch S, Li Z, Adany I, Liu Z, Zhuge W, Piatak M Jr, Lifson J, McClure H, Narayan O: Immunization of macaques with live simian human immunodeficiency virus (SHIV) vaccines conferred protection against AIDS induced by homologous and heterologous SHIVs and simian immunodeficiency virus. Virology 2002, 301:189-205.

15. Reynolds MR, Weiler AM, Weisgrau KL, Piaskowski SM, Furlott JR, Weinfurter JT, Kaizu M, Soma T, León EJ, MacNair C, Leaman DP, Zwick MB, Gostick E, Musani SK, Price DA, Friedrich TC, Rakasz EG, Wilson NA, McDermott AB, Boyle R, Allison DB, Burton DR, Koff WC, Watkins DI:
Macaques vaccinated with live-attenuated SIV control replication of heterologous virus. J Exp Med 2008, 205:2537-2550.

16. Baba TW, Jeong YS, Pennick D, Bronson R, Greene MF, Ruprecht RM: Pathogenicity of live, attenuated SIV after mucosal infection of neonatal macaques. Science 1995, 267:1820-1825.

17. Whatmore AM, Cook N, Hall GA, Sharpe S, Rud EW, Cranage MP: Repair and evolution of nef in vivo modulates simian immunodeficiency virus virulence. J Virol 1995, 69:5117-5123.

18. Learmont JC, Geczy AF, Mills J, Ashton LJ, Raynes-Greenow CH, Garsia RJ, Dyer WB, McIntyre L, Oelrichs RB, Rhodes DI, Deacon NJ, Sullivan JS: Immunologic and virologic status after 14 to 18 years of infection with an attenuated strain of HIV-1. A report from the Sydney Blood Bank Cohort. N Engl J Med 1999, 340:1715-1722.

19. Sawai ET, Hamza MS, Ye M, Shaw KE, Luciw PA: Pathogenic conversion of live attenuated simian immunodeficiency virus vaccines is associated with expression of truncated Nef. J Virol 2000, 74:2038-2045.

20. Hofmann-Lehmann R, Vlasak J, Williams AL, Chenine AL, McClure HM, Anderson DC, O'Neil S, Ruprecht RM: Live attenuated, nef-deleted SIV is pathogenic in most adult macaques after prolonged observation. AIDS 2003, 17:157-166.

21. Friedrich TC, Watkins DI: Wanted: correlates of vaccine-induced protection against simian immunodeficiency virus. Curr Opin HIV AIDS 2008, 3:393-398.

22. Stahl-Hennig C, Dittmer U, Nisslein T, Pekrun $K$, Petry H, Jurkiewicz E, Fuchs D, Wachter H, Rud EW, Hunsmann G: Attenuated SIV imparts immunity to challenge with pathogenic spleen-derived SIV but cannot prevent repair of the nef deletion. Immunol Lett 1996, 51:129-135.

23. Wyand MS, Manson KH, Garcia-Moll M, Montefiori D, Desrosiers RC: Vaccine protection by a triple deletion mutant of simian immunodeficiency virus. J Virol 1996, 70:3724-3733.

24. Almond N, Rose J, Sangster R, Silvera P, Stebbings R, Walker B, Stott EJ: Mechanisms of protection induced by attenuated simian immunodeficiency virus. I. Protection cannot be transferred with immune serum. J Gen Virol 1997, 78:1919-1922.

25. Connor RI, Montefiori DC, Binley JM, Moore JP, Bonhoeffer S, Gettie A, Fenamore EA, Sheridan KE, Ho DD, Dailey PJ, Marx PA: Temporal analyses of virus replication, immune responses, and efficacy in rhesus macaques immunized with a live, attenuated simian immunodeficiency virus vaccine. J Virol 1998, 72:7501-7509.

26. Langlois AJ, Desrosiers RC, Lewis MG, KewalRamani VN, Littman DR, Zhou JY, Manson K, Wyand MS, Bolognesi DP, Montefiori DC: Neutralizing antibodies in sera from macaques immunized with attenuated simian immunodeficiency virus. J Virol 1998, 72:6950-6955.

27. Nixon DF, Donahoe SM, Kakimoto WM, Samuel RV, Metzner KJ, Gettie A Hanke T, Marx PA, Connor Rl: Simian immunodeficiency virus-specific cytotoxic $T$ lymphocytes and protection against challenge in rhesus macaques immunized with a live attenuated simian immunodeficiency virus vaccine. Virology 2000, 266:203-210.

28. Johnson RP: Mechanisms of protection against simian immunodeficiency virus infection. Vaccine 2002, 20:1985-1987.

29. Almond NM, Stott EJ, Berry N, Wade-Evans AM, Hull R, Lines J, Silvera P, Sangster R, Corcoran T, Rose J, Walker KB: Mechanisms of protection induced by attenuated simian immunodeficiency virus. Virology 2002, 296:338-353.

30. Abel K, Compton L, Rourke T, Montefiori D, Lu D, Rothaeusler K, Fritts L, Bost K, Miller CJ: Simian-human immunodeficiency virus SHIV89.6induced protection against intravaginal challenge with pathogenic SIVmac239 is independent of the route of immunization and is associated with a combination of cytotoxic T-lymphocyte and alpha interferon responses. J Virol 2003, 77:3099-3118.

31. Sharpe SA, Cope A, Dowall S, Berry N, Ham C, Heeney JL, Hopkins D, Easterbrook L, Dennis M, Almond N, Cranage M: Macaques infected longterm with attenuated simian immunodeficiency virus (SIVmac) remain resistant to wild-type challenge, despite declining cytotoxic $T$ lymphocyte responses to an immunodominant epitope. J Gen Virol 2004, 85:2591-2602.

32. Tenner-Racz K, Stahl Hennig C, Uberla K, Stoiber H, Ignatius R, Heeney J, Steinman RM, Racz P: Early protection against pathogenic virus infection at a mucosal challenge site after vaccination with attenuated simian immunodeficiency virus. Proc Natl Acad Sci USA 2004, 101:3017-3022. 
33. Schmitz JE, Johnson RP, McClure HM, Manson KH, Wyand MS, Kuroda MJ, Lifton MA, Khunkhun RS, McEvers KJ, Gillis J, Piatak M, Lifson JD, Grosschupff G, Racz P, Tenner-Racz K, Rieber EP, Kuus-Reichel K, Gelman RS, Letvin NL, Montefiori DC, Ruprecht RM, Desrosiers RC, Reimann KA: Effect of CD8+ lymphocyte depletion on virus containment after simian immunodeficiency virus SIVmac251 challenge of live attenuated SIVmac239delta3-vaccinated rhesus macaques. J Virol 2005, 79:8131-8141.

34. Stebbings R, Berry N, Waldmann H, Bird P, Hale G, Stott J, North D, Hull R, Hall J, Lines J, Brown S, D'Arcy N, Davis L, Elsley W, Edwards C, Ferguson D, Allen J, Almond N: CD8+ lymphocytes do not mediate protection against acute superinfection 20 days after vaccination with a live attenuated simian immunodeficiency virus. J Virol 2005, 79:12264-122672.

35. Gauduin MC, Yu Y, Barabasz A, Carville A, Piatak M, Lifson JD, Desrosiers RC, Johnson RP : Induction of a virus-specific effector-memory CD4+ T cell response by attenuated SIV infection. J Exp Med 2006, 203:2661-2672.

36. Goletti D, Macchia I, Leone P, Pace M, Sernicola L, Pavone-Cossut MR, Maggiorella MT, Cafaro A, Ensoli B, Titti F: Innate anti-viral immunity is associated with the protection elicited by the simian immunodeficiency virus (SIV) live attenuated virus vaccine in cynomolgus monkeys. Med Sci Monit 2006, 12:BR330-BR340.

37. Berry N, Stebbings R, Ferguson D, Ham C, Alden J, Brown S, Jenkins A Lines J, Duffy L, Davis L, Elsley W, Page M, Hull R, Stott J, Almond N: Resistance to superinfection by a vigorously replicating, uncloned stock of simian immunodeficiency virus (SIVmac251) stimulates replication of a live attenuated virus vaccine (SIVmacC8). J Gen Virol 2008, 89:2240-2251.

38. Salha MD, Cheynier R, Halwani R, McGrath H, Langaee TY, Yassine Diab B, Fournier J, Parenteau M, Edgar J, Ko D, Sherring A, Bogdanovic D, Sekaly RP, Rud EW: Persistence of restricted CD4 T cell expansions in SIV-infected macaques resistant to SHIV89.6P superinfection. Virology 2008, 377:239-247

39. Mansfield K, Lang SM, Gauduin MC, Sanford HB, Lifson JD, Johnson RP, Desrosiers RC: Vaccine protection by live, attenuated simian immunodeficiency virus in the absence of high-titer antibody responses and high-frequency cellular immune responses measurable in the periphery. J Virol 2008, 82:4135-4148.

40. Johnson RP, Lifson JD, Czajak SC, Cole KS, Manson KH, Glickman R, Yang J, Montefiori DC, Montelaro R, Wyand MS, Desrosiers RC: Highly attenuated vaccine strains of simian immunodeficiency virus protect against vaginal challenge: inverse relationship of degree of protection with level of attenuation. J Virol 1999, 73:4952-4961.

41. van der Kuyl AC, Kozaczynska K, Arien KK, Gali Y, Balazs VR, Dekker SJ, Zorgdrager F, Vanham G, Berkhout B, Cornelissen M: Analysis of infectious virus clones from two HIV-1 superinfection cases suggests that the primary strains have lower fitness. Retrovirology 2010, 7:60-74.

42. Denesvre C, Le Grand R, Boissin-Cans F, Chakrabarti L, Hurtrel B, Vaslin B Dormont $D$, Sonigo P: Highly attenuated SIVmac142 is immunogenic but does not protect against SIVmac251 challenge. AIDS Res Hum Retroviruses 1995, 11:1397-1406.

43. Berry N, Stott J, Hull R, Walker B, Lines J, Elsley W, Brown S, Wade-Evans A, Davis G, Cowie J, Sethi M, Almond N: Vaccination with live attenuated simian immunodeficiency virus for 21 days protects against superinfection. Virology 2004, 330:249-260.

44. Guy-Grand D, Vassalli P: Gut intraepithelial T lymphocytes. Curr Opin Immunol 1993, 5:247-252.

45. Viney JL: The anatomical basis of intestinal immunity. Immunol Rev 1997, 156:145-66.

46. Smit-McBride Z, Mattapallil JJ, McChesney M, Ferrick D, Dandekar S: Gastrointestinal T lymphocytes retain high potential for cytokine responses but have severe CD4(+) T-cell depletion at all stages of simian immunodeficiency virus infection compared to peripheral lymphocytes. J Virol 1998, 72:6646-6656.

47. Ganusov W, De Boer RJ: Do most lymphocytes in humans really reside in the gut? Trends Immunol 2007, 28:514-518.

48. Veazey RS, Lackner AA: The gastrointestinal tract and the pathogenesis of AIDS. AIDS 1998, 12(Suppl A)):S35-S42.

49. Agace WW, Roberts Al, Wu L, Greineder C, Ebert EC, Parker CM: Human intestinal lamina propria and intraepithelial lymphocytes express receptors specific for chemokines induced by inflammation. Eur Immunol 2000, 30:819-826.

50. Anton PA, Elliott J, Poles MA, McGowan IM, Matud J, Hultin LE, GrovitFerbas K, Mackay CR, Chen ISY, Giorgi JV: Enhanced levels of functional
HIV-1 co-receptors on human mucosal T cells demonstrated using intestinal biopsy tissue. AIDS 2000, 14:1761-1765.

51. Chen Z, Gettie A, Ho DD, Marx PA: Primary SIVsm isolates use the CCR5 coreceptor from sooty mangabeys naturally infected in west Africa: a comparison of coreceptor usage of primary SIVsm, HIV-2, and SIVmac. Virology 1998, 246:113-124.

52. Zhang Y, Lou B, Lal RB, Gettie A, Marx PA, Moore JP: Use of inhibitors to evaluate coreceptor usage by simian and simian/human immunodeficiency viruses and human immunodeficiency virus type 2 in primary cells. J Virol 2000, 74:6893-68910.

53. Moore JP, Kitchen SG, Pugach P, Zack JA: The CCR5 and CXCR4 coreceptors-central to understanding the transmission and pathogenesis of human immunodeficiency virus type 1 infection. AIDS Res Hum Retroviruses 2004, 20:111-126.

54. Brenchley JM, Schacker TW, Ruff LE, Price DA, Taylor JH, Beilman GJ, Nguyen PL, Khoruts A, Larson M, Haase AT, Douek DC: CD4+ T cell depletion during all stages of HIV disease occurs predominantly in the gastrointestinal tract. J Exp Med 2004, 200:749-759.

55. Mehandru S, Poles MA, Tenner-Racz K, Horowitz A, Hurley A, Hogan C, Boden D, Racz P, Markowitz M: Primary HIV-1 infection is associated with preferential depletion of CD4+ T lymphocytes from effector sites in the gastrointestinal tract. J Exp Med 2004, 200:761-770.

56. Li Q, Duan L, Estes JD, Ma ZM, Rourke T, Wang Y, Reilly C, Carlis J, Miller CJ, Haase AT : Peak SIV replication in resting memory CD4+ T cells depletes gut lamina propria CD4+ T cells. Nature 2005, 434:1148-1152.

57. Mattapallil JJ, Douek DC, Hill B, Nishimura Y, Martin M, Roederer M: Massive infection and loss of memory CD4+ T cells in multiple tissues during acute SIV infection. Nature 2005, 434:1093-1099.

58. Reeves RK, Gillis J, Wong FE, Johnson RP: Vaccination with SIVmac239Deltanef activates CD4+ T cells in the absence of CD4 T-cell loss. J Med Primatol 2009, 38(Suppl 1):8-16.

59. Picker LJ, Reed-Inderbitzin EF, Hagen SI, Edgar JB, Hansen SG, Legasse A, Planer S, Piatak M, Lifson JD, Maino VC, Axthelm MK, Villinger F: IL-15 induces CD4 effector memory $T$ cell production and tissue emigration in nonhuman primates. J Clin Invest 2006, 116:1514-1524.

60. Okoye A, Park H, Rohankhedkar M, Coyne-Johnson L, Lum R, Walker JM, Planer SL, Legasse AW, Sylwester AW, Piatak M, Lifson JD, Sodora DL, Villinger F, Axthelm MK, Schmitz JE, Picker LJ: Profound CD4+/CCR5+ T cell expansion is induced by CD8+ lymphocyte depletion but does not account for accelerated SIV pathogenesis. J Exp Med 2009, 206:1575-1588.

61. Rud EW, Cranage M, Yon J, Quirk J, Ogilvie L, Cook N, Webster S, Dennis M, Clarke BE: Molecular and biological characterization of simian immunodeficiency virus macaque strain $32 \mathrm{H}$ proviral clones containing nef size variants. J Gen Virol 1994, 75(Pt 3):529-543.

62. Stebbings R, Stott J, Almond N, Hull R, Lines J, Silvera P, Sangster R, Corcoran T, Rose J, Cobbold S, Gotch F, McMichael A, Walker B: Mechanisms of protection induced by attenuated simian immunodeficiency virus. II. Lymphocyte depletion does not abrogate protection. AIDS Res Hum Retroviruses 1998, 14:1187-1198.

63. Qin S, Rottman JB, Myers P, Kassam N, Weinblatt M, Loetscher M, Koch AE Moser B, Mackay CR: The chemokine receptors CXCR3 and CCR5 mark subsets of T cells associated with certain inflammatory reactions. J Clin Invest 1998, 101:746-754.

64. Balashov KE, Rottman JB, Weiner HL, Hancock WW: CCR5 (+) and CXCR3 (+) T cells are increased in multiple sclerosis and their ligands MIP1alpha and IP-10 are expressed in demyelinating brain lesions. Proc Natl Acad Sci USA 1999, 96:6873-6878.

65. Ebert LM, McColl SR: Up-regulation of CCR5 and CCR6 on distinct subpopulations of antigen-activated CD4+ T lymphocytes. J Immunol 2002, 168:65-72.

66. Loetscher P, Uguccioni M, Bordoli L, Baggiolini M, Moser B, Chizzolini C, Dayer JM: CCR5 is characteristic of Th1 lymphocytes. Nature 1998, 391:344-345

67. Olsson J, Poles M, Spetz AL, Elliott J, Hultin L, Giorgi J, Andersson J, Anton P: Human immunodeficiency virus type 1 infection is associated with significant mucosal inflammation characterized by increased expression of CCR5, CXCR4, and beta-chemokines. J Infect Dis 2000, 182:1625-1635

68. Oki M, Ohtani $H$, Kinouchi $Y$, Sato E, Nakamura $S$, Matsumoto $T$, Nagura $H$, Yoshie O, Shimosegawa T: Accumulation of CCR5+ T cells around RANTES 
+ granulomas in Crohn's disease: a pivotal site of Th1-shifted immune response? Lab Invest 2005, 85:137-145.

69. Sallusto F, Geginat J, Lanzavecchia A: Central memory and effector memory T cell subsets: function, generation, and maintenance. Annu Rev Immunol 2004, 22:745-763.

70. Clarke S, Almond N, Berry N: Simian immunodeficiency virus Nef gene regulates the production of 2-LTR circles in vivo. Virology 2003, 306:100-108.

71. Ling B, Veazey RS, Hart M, Lackner AA, Kuroda M, Pahar B, Marx PA: Early restoration of mucosal CD4 memory CCR5 T cells in the gut of SIVinfected rhesus predicts long term non-progression. AIDS 2007 21:2377-2385.

72. Monceaux V, Viollet L, Petit F, Cumont MC, Kaufmann GR, Aubertin AM, Hurtrel B, Silvestri G, Estaquier J: CD4+ CCR5+ T-cell dynamics during simian immunodeficiency virus infection of Chinese rhesus macaques. J Virol 2007, 81:13865-13875.

73. Jin X, Bauer DE, Tuttleton SE, Lewin S, Gettie A, Blanchard J, Irwin CE, Safrit JT, Mittler J, Weinberger L, Kostrikis LG, Zhang L, Perelson AS, Ho DD: Dramatic rise in plasma viremia after CD8(+) T cell depletion in simian immunodeficiency virus-infected macaques. J Exp Med 1999, 189:991-998.

74. Schmitz JE, Kuroda MJ, Santra S, Sasseville VG, Simon MA, Lifton MA, Racz P, Tenner-Racz K, Dalesandro M, Scallon BJ, Ghrayeb J, Forman MA, Montefiori DC, Rieber EP, Letvin NL, Reimann KA: Control of viremia in simian immunodeficiency virus infection by CD8+ lymphocytes. Science 1999, 283:857-860

75. Metzner KJ, Jin X, Lee FV, Gettie A, Bauer DE, Di Mascio M, Perelson AS, Marx PA, Ho DD, Kostrikis LG, Connor Rl: Effects of in vivo CD8(+) T cell depletion on virus replication in rhesus macaques immunized with a live, attenuated simian immunodeficiency virus vaccine. J Exp Med 2000, 191:1921-1931.

76. Lifson JD, Rossio JL, Piatak M Jr, Parks T, Li L, Kiser R, Coalter V, Fisher B, Flynn BM, Czajak S, Hirsch VM, Reimann KA, Schmitz JE, Ghrayeb J, Bischofberger N, Nowak MA, Desrosiers RC, Wodarz D: Role of CD8(+) lymphocytes in control of simian immunodeficiency virus infection and resistance to rechallenge after transient early antiretroviral treatment. J Virol 2001, 75:10187-10199.

77. Sallusto F, Lenig D, Förster R, Lipp M, Lanzavecchia A: Two subsets of memory T lymphocytes with distinct homing potentials and effector functions. Nature 1999, 401:708-712.

78. Amyes E, McMichael AJ, Callan MF: Human CD4+ T cells are predominantly distributed among six phenotypically and functionally distinct subsets. J Immunol 2005, 175:5765-5773.

79. Nethe $M$, Berkhout $B$ and van der Kuyl AC: Retroviral superinfection resistance. Retrovirology 2005, 2:52-64.

80. Pandrea I, Apetrei C, Gordon S, Barbercheck J, Dufour J, Bohm R, Sumpter B, Roques P, Marx PA, Hirsch VM, Kaur A, Lackner AA, Veazey RS, Silvestri G: Paucity of CD4+CCR5+ T cells is a typical feature of natural SIV hosts. Blood 2007, 109:1069-1076.

81. Picker $L$, Hagen SI, Lum R, Reed-Inderbitzin EF, Daly LM, Sylwester AW, Walker JM, Siess DC, Piatak M, Wang JC, Allison DB, Maino VC, Lifson JD, Kodama T, Axthelm MK: Insufficient production and tissue delivery of CD4+ memory $T$ cells in rapidly progressive simian immunodeficiency virus infection. J Exp Med 2004, 200:1299-1314.

82. Ferguson D, Wade-Evans A, Elsley W, Sangster R, Silvera P, MacManus S, Davis G, Corcoran T, Berry N, Brown S, Jenkins A, Cowie J, Sethi M, Hull R, Stebbings R, Lines J, Norley S, Stott EJ, Almond N: Preparation and characterization of new challenge stocks of SIVmac32 H J5 following rapid serial passage of virus in vivo. J Med Primatol 2007, 36:131-142.

doi:10.1186/1742-4690-8-8

Cite this article as: Li et al:: Vaccination with live attenuated simian immunodeficiency virus causes dynamic changes in intestinal CD4 +CCR5+ T cells. Retrovirology 2011 8:8.

\section{Submit your next manuscript to BioMed Central and take full advantage of:}

- Convenient online submission

- Thorough peer review

- No space constraints or color figure charges

- Immediate publication on acceptance

- Inclusion in PubMed, CAS, Scopus and Google Scholar

- Research which is freely available for redistribution

Submit your manuscript at www.biomedcentral.com/submit
C Biomed Central 